\title{
Catalytic oxidation of organic pollutants
}

\author{
Wiesław J. Parus ${ }^{1}$, Wojciech Paterkowski² \\ ${ }^{1}$ West Pomeranian University of Technology, Institute of Chemistry and Environmental Protection, al. Piastów 42, \\ 71-065 Szczecin, Poland, e-mail: wparus@zut.edu.pl \\ ${ }^{2}$ West Pomeranian University of Technology, Institute of Chemical Engineering and Environmental Protection Processes, \\ al. Piastów 42, 71-065 Szczecin, e-mail: wpater@zut.edu.pl
}

\begin{abstract}
The paper presents the results of the measurements of the catalytic activity of $\mathrm{V}_{2} \mathrm{O}_{5} / \mathrm{TiO}_{2}$ and $\mathrm{MoO}_{3} / \mathrm{TiO}_{2}$ catalysts $\left(8,10,12\right.$ and $15 \mathrm{wt} \%$ of $\mathrm{V}_{2} \mathrm{O}_{5}$ or $\mathrm{MoO}_{3}$ on $\mathrm{TiO}_{2}$ - anatase, respectively), prepared in our laboratory, in the complete oxidation (combustion) process of chosen volatile organic pollutants of the air such as methanol and n-butyl acetate. The activity of these catalysts was compared with the activity of industrial catalysts: supported platinum - Pt-p (0.15 wt \% of Pt on $\left.\gamma-\mathrm{Al}_{2} \mathrm{O}_{3}\right)$ and MCA (15 wt \% of $\mathrm{CuO}$ and $6 \mathrm{wt}$ $\%$ of $\mathrm{ZnO}$ on $\gamma-\mathrm{Al}_{2} \mathrm{O}_{3}$ ). The investigations were carried out in the kinetic region (powder of the catalysts with the diameter in the range of $1.02-1.2 \cdot 10^{-4} \mathrm{~m}$ ) and for the chosen catalysts also in the diffusion region (the grains of the catalysts having the diameter of $2.5 \cdot 10^{-3} \mathrm{~m}$ ). On the basis of the obtained results the analysis of the process was performed.

It has been stated that reaction rate is well-described by the first order equation in relation to the methanol or n-butyl acetate concentration. On the basis of the obtained results in the kinetic region for all the applied catalysts the parameters of Arrhenius equation were determinated.

The comparison of the results for the kinetic region with the results for the diffusion region for the chosen catalysts allowed the calculation of the effective coefficients of diffusion. The parameters of Arrhenius equations as well as the effective coefficients of diffusion show a good correlation with the values obtained for the catalytic combustion of other organic pollutants of the air.

The measurements were carried out using a flow tubular reactor. The flow rate of the reaction mixture was kept constant $20 \mathrm{dm}^{3} / \mathrm{h}\left(5.56 \cdot 10^{-6} \mathrm{~m}^{3} / \mathrm{s}\right)$ in each test, using the space velocity of $20 \mathrm{~s}^{-1}$. It has been stated that the use of the applied catalysts led to the almost total oxidative destruction of both pollutants. Only $\mathrm{H}_{2} \mathrm{O}$ and $\mathrm{CO}_{2}$ were found as the final products of the reaction. The complete oxidation of the methanol process runs at the lower temperature than that of the complete oxidation process of n-butyl acetate. The most active at the combustion of methanol was the Pt-p catalyst. It demonstrates a comparable activity to molybdenum - titanium catalysts and the slightly lower activity than vanadium - titanium catalysts in the combustion of the $\mathrm{n}$ - butyl acetate process. The MCA catalyst was less active than the others in the oxidation of both compounds. The structures of the catalysts were tested using the X-ray analysis (XRD), infrared spectroscopy and scanning microscopy (SEM).

The results of the investigations show that $\mathrm{V}_{2} \mathrm{O}_{5} / \mathrm{TiO}_{2}$ and $\mathrm{MoO}_{3} / \mathrm{TiO}_{2}$ catalysts, especially the most active of them the $8 \% \mathrm{~V}_{2} \mathrm{O}_{5} / \mathrm{TiO}_{2}$ catalyst can be used in industrial systems for the purification of the air and industrial waste gases with VOCs, replacing the more expensive noble metals supported catalysts.
\end{abstract}

Keywords: catalytic oxidation of methanol and n-butyl acetate, $\mathrm{V}_{2} \mathrm{O}_{5} / \mathrm{TiO}_{2}$ and $\mathrm{MoO}_{3} / \mathrm{TiO}_{2}$ catalysts, macrokinetics of oxidation process.

\section{INTRODUCTION}

Different volatile organic compounds are emitted to atmosphere from various industrial plants. Among them there are hydrocarbons and also the organic compounds containing sulphur, nitrogen, oxygen and halogens. The type and the amount of the pollutants influence the method which is applied for their removal from the gas effluent streams. There are many different techniques for VOCs removal, such as adsorption, absorption, biofiltration, thermal incineration, and catalytic combustion (complete oxidation). For many years the catalytic combustion methods have been the ones to be the most often applied to reduce the emissions of volatile organic compounds from stationary sources ${ }^{\mathbf{1}, \mathbf{2}}$. They can be used effectively in a wide range of pollutants concentrations and waste gas flow rates. Furthermore, when the gases contain only hydrocarbons and oxygen-containing organic compounds only non-toxic $\mathrm{H}_{2} \mathrm{O}$ and $\mathrm{CO}_{2}$ are the products of the reaction. Additionally, these methods are cheaper than other technologies. It is the reason why at many scientific centres of the world the further investigations of the catalytic combustion of different organic compounds processes are conducted. The aim of these investigations is to obtain the active, cheap and resistant to the poisons catalysts for combustion processes.

Two types of the catalysts are used in catalytic oxidation: supported noble metals or metal oxides. Among noble metals, Pt and Pd are the most frequently used for the complete oxidation of $\mathrm{VOCs}^{3-8}$, usually supported on different carriers. The catalysts based on the metal oxides as an active components, contain oxides such as: $\mathrm{CuO}$, $\mathrm{Mn}_{2} \mathrm{O}_{3}, \mathrm{Fe}_{2} \mathrm{O}_{3}, \mathrm{Co}_{2} \mathrm{O}_{3}, \mathrm{NiO}, \mathrm{MgO}, \mathrm{ZnO}, \mathrm{Cr}_{2} \mathrm{O}_{3}, \mathrm{CeO}_{2}$ or their mixtures ${ }^{-13}$. These catalysts are manufactured in the form of different grains, pellets as well as supported on an oxide, mainly $\mathrm{Al}_{2} \mathrm{O}_{3}$.

In the 70s a new generation of the catalysts for the purification of effluent industrial gases, mainly with nitrogen oxides, has been developed ${ }^{14}$. The new catalysts were obtained by supporting chosen transition metal oxides $\left(\mathrm{V}_{2} \mathrm{O}_{5}\right.$ and $\left.\mathrm{MoO}_{3}\right)$ on $\mathrm{TiO}_{2}$ (anatase). The methods of the preparation of such catalysts were described in the litera- 
ture $^{15}$. These catalysts have high activity in the selective catalytic reduction of nitrogen oxides with the ammonia process (SCR process) and furthermore at the temperatures higher than $300^{\circ} \mathrm{C}$ they are resistant to sulphur oxides $^{13,14}$. Additionally, they are cheaper than other catalysts ${ }^{14,15}$.

That is why it was interesting to determinate the activity of the $\mathrm{V}_{2} \mathrm{O}_{5}-\mathrm{TiO}_{2}$ and $\mathrm{MoO}_{3}-\mathrm{TiO}_{2}$ catalysts also in the catalytic combustion of volatile organic compounds processes. Waste gases from industrial plants very often contain both organic compounds and nitrogen oxides. In the case of high activity of vanadium - titanium and molybdenum - titanium catalysts also in the oxidation of VOCs, they could be applied for the removal from industrial gases of such pollutants together with nitrogen oxides.

\section{THEORETICAL BASIS}

The process rate over porous catalysts also depends on the rate of mass and heat transfer from the stream of the gas to the external surface of the catalyst and inside its grains. To investigate the combustion of the organic compounds process it is necessary to consider the chemical reaction together with the mass transfer when the process occurs in the isothermal conditions or the chemical reaction together with the mass and heat transfer in the nonisothermal conditions.

The kinetics of the reaction of the catalytic combustion of organic pollutants in the air is well described by the first order equation in relation to the concentration of the pollutant ${ }^{16}$. Thus, the reaction rate can be expressed by the equation:

$r_{0}=c_{0} \cdot \frac{d \alpha}{d \tau}=k_{v} \cdot c_{0}(1-\alpha)$

Usually the rate constant of reaction $\mathrm{k}_{\mathrm{v}}$ is given by the Arrhenius equation:

$\mathrm{k}=\mathrm{A} \exp (-\mathrm{E} / \mathrm{RT})=\mathrm{A} \exp (-\mathrm{B} / \mathrm{T})$

The heterogeneous catalytic reaction in the kinetic region should be carried out using the powder of the catalyst, the size of which must be early determined experimentally. It can be done by determining the process rate for the particles of the catalyst having different dimensions, whereas the other parameters of the process such as the temperature, the flow rate of the reaction mixture, the inlet concentration of the reagents in the gases and the effective coefficient of the diffusion are kept constant ${ }^{17}$. When the increasingly smaller grains of the catalyst are applied, the process rate increases to the maximum value, which is obtained for such dimension of the catalyst grains for which the process runs in the kinetic region. Further decrease of the catalyst grains does not accelerate the process rate.

In the industrial reactors the catalysts in the form of porous pellets or blocks are usually used. In that case the real rate of the process depends not only on the reaction rate, but also on the rate of external diffusion (mass transfer of the pollutant from the stream of the gas to the external surface of the catalyst) and on the rate of internal diffusion (mass transfer inside of the porous grain of the catalysts). Most often the rate of the external diffusion is higher than other stages of the process and mainly depends on the turbulency of gas flow in the reactor. It has been assumed that when the linear velocity of gas flow is of $0.2 \mathrm{~m} / \mathrm{s}$ and more, the external diffusion does not influence the total process rate of the heterogenous catalytic reaction ${ }^{17}$. When the process is only controlled both by the internal diffusion and the chemical reaction, its rate is described by equation:

$r(\alpha, T)=r_{0} \cdot \eta$

For the first order equation of the reaction rate, the spherical shape of catalyst grains and when the process occurs at constant temperature, the effectivity coefficient $\eta$ is described by the equation:

$\eta=\frac{3}{\Phi_{s 1}} \cdot\left(\frac{1}{\tanh \Phi_{s 1}}-\frac{1}{\Phi_{s 1}}\right)$

where:

$\Phi_{\mathrm{s} 1}-$ the Thiele's modulus

$\Phi_{s 1}=R_{0} \cdot \sqrt{\frac{k_{v}}{D_{e f}}}$

When the values of Thiele's modulus $\Phi_{\mathrm{s} 1}$ and the rate constant $\mathrm{k}_{\mathrm{v}}$ are known, then the effective coefficient of the diffusion can be calculated from the formula:

$D_{e f}=\frac{R_{0}^{2} \cdot k_{v}}{\Phi_{s 1}^{2}}$

Figure 1 shows the relation between $\eta$ and $\Phi_{\mathrm{s} 1}$, which was used for the calculation of $D_{\text {ef }}$.

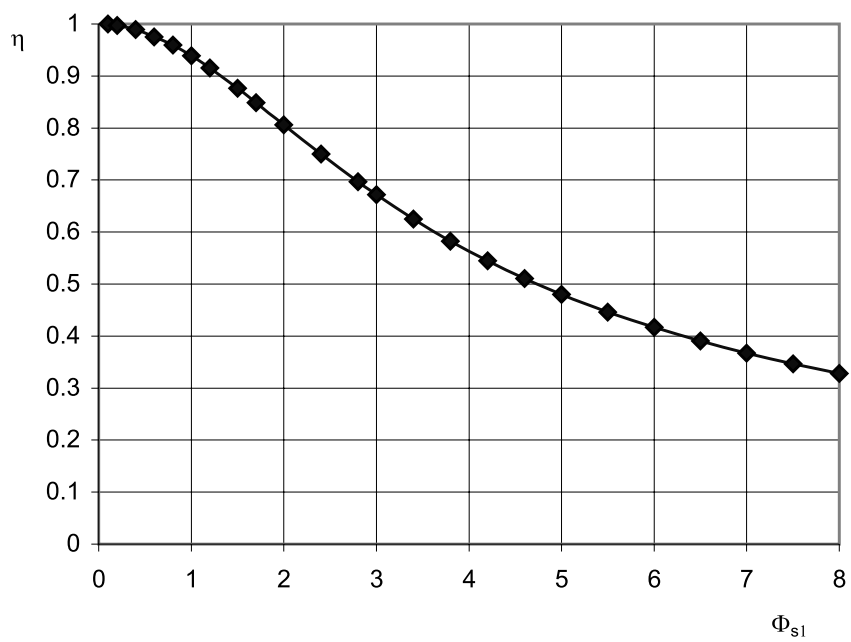

Figure 1. The relation between of $\eta$ and $\Phi_{\mathrm{s} 1}$ for the first order reaction

In the investigations of the kinetics of the catalytic combustion (total oxidation) of hydrocarbons and others organic pollutants of the air the tubular reactor is usually applied. The design reactor equation has the form ${ }^{\mathbf{1 6}}$ :

$\frac{m_{k}}{\dot{F}_{0 v}}=c_{0} \cdot \int_{0}^{\alpha} \frac{d \alpha}{r(\alpha, T)}$

After the integration of equation (7) we get

- for the kinetic region

$-\ln (1-\alpha)_{\text {kin }}=\frac{m_{k}}{\dot{F}_{0 V}} \cdot \mathrm{k}$

- for the diffusion region

$-\ln (1-\alpha)_{\mathrm{dyf}}=\frac{m_{k}}{\dot{F}_{0 V}} \cdot \eta \cdot \mathrm{k}$ 
When the measurements for the powder and for the grains of the catalyst are carried out at the same temperature and under the same flow rate of gases we obtain

$\eta=\frac{\ln (1-\alpha)_{d y f}}{\ln (1-\alpha)_{k i n}}$

On the basis of the experimental results, using equation (10), the effectivity coefficient $\eta$ can be calculated. When its value is known, the Thiele's modulus $\Phi_{\mathrm{s} 1}$ is determinated from Figure 1.

\section{EXPERIMENTAL}

The laboratory samples of the investigated, vanadiumtitanium and molybdenum-titanium catalysts were obtained by the impregnation of the support $-\mathrm{TiO}_{2}$ (anatase, BET surface area $62.5 \mathrm{~m}^{2} / \mathrm{g}$ ) with an aqueous solution of ammonium metavanadate $\mathrm{NH}_{4} \mathrm{VO}_{3}$ or ammonium paramolybdate $\left(\mathrm{NH}_{4}\right)_{6} \mathrm{Mo}_{7} \mathrm{O}_{24}$, in appropriate concentration to get loading in the range of $8-15 \mathrm{wt}$. $\%$ of $\mathrm{V}_{2} \mathrm{O}_{5}$ or $\mathrm{MoO}_{3}$. After the impregnation the mixtures were dried at the temperature of $110^{\circ} \mathrm{C}$ and next were calcinated in air for 5 hours at the temperature of $350^{\circ} \mathrm{C}$. The catalyst powder was pelletised and subsequently crushed to obtain the powder having the particle size fraction with an average diameter of $1.02-1.2 \cdot 10^{-4} \mathrm{~m}$ (for the investigations in the kinetic region) and the grains of the catalysts with the diameter of $2.5 \cdot 10^{-3} \mathrm{~m}$ (for the investigations in the diffusion region). According to this procedure the vanadium-titanium and molybdenum-titanium catalysts containing $8,10,12$ or 15 wt. \% of active components i.e. $\mathrm{V}_{2} \mathrm{O}_{5}$ or $\mathrm{MoO}_{3}$ were prepared. Using the same method of preparation the catalyst containing $10 \mathrm{wt}$. $\%$ of $\mathrm{V}_{2} \mathrm{O}_{5}$ or $\mathrm{MoO}_{3}$ on $\mathrm{TiO}_{2}$ in the form of hydrogel as support (BET surface area $260 \mathrm{~m}^{2} / \mathrm{g}$ ) were obtained. These catalysts were signified by the letter $\mathrm{H}$. The industrial Pt-p and
MCA catalysts were manufactured by the chemical plants in Poland.

The investigations of the activity of the tested catalysts were carried out using the experimental set-up, schematically shown in Figure 2.

The feed air from the high-pressure air cylinder (7) was divided into two streams. One stream was passed through the glass spheres packed column (3). To the top of the column the liquid methanol or n-butyl acetate was introduced. In the column the air was saturated with the vapour of one of these compounds. The temperature of the saturator was held constant using the water bath. The second stream was pure air. Both streams were directed to the mixer of the gases (4), where they were mixed. The total volume flow rate of the air-VOC mixture was measured by a gas flowmeter (14). Using the control needle valves (18), the proper contribution of the total air stream and the desired concentration of the pollutant in the mixture were obtained. The mixture of the gases was introduced into the tubular quartz glass reactor (1) in the shape of a U-pipe (the outer diameter of the pipe of $9 \cdot 10^{-3} \mathrm{~m}$ and the inner diameter of $6 \cdot 10^{-3} \mathrm{~m}$ ). It was heated by an electric furnace (5). The catalyst bed was placed in the reactor on the grate from the quartz wool (8) and was covered with a plug of quartz wool, as the protection against the fine catalyst grains getting blown out with the stream of gases. The reaction temperature was controlled by the thermocouple placed in the middle of the reactor inside the catalyst bed. The sampling ports were fitted at the inlet and outlet of the catalytic reactor.

The measurements were performed as follows. After the placement of the catalyst sample (usually $5 \cdot 10^{-4} \mathrm{~kg}$ ) in the reactor, it was pre-heated to the temperature up to $100^{\circ} \mathrm{C}$. Next the feed air and the feed liquid methanol or n-butyl acetate were turned out to the saturator. The required concentration of VOC in the mixture of the gases and the temperature of the reaction were chosen. When the concentration and the reaction temperature were constant,

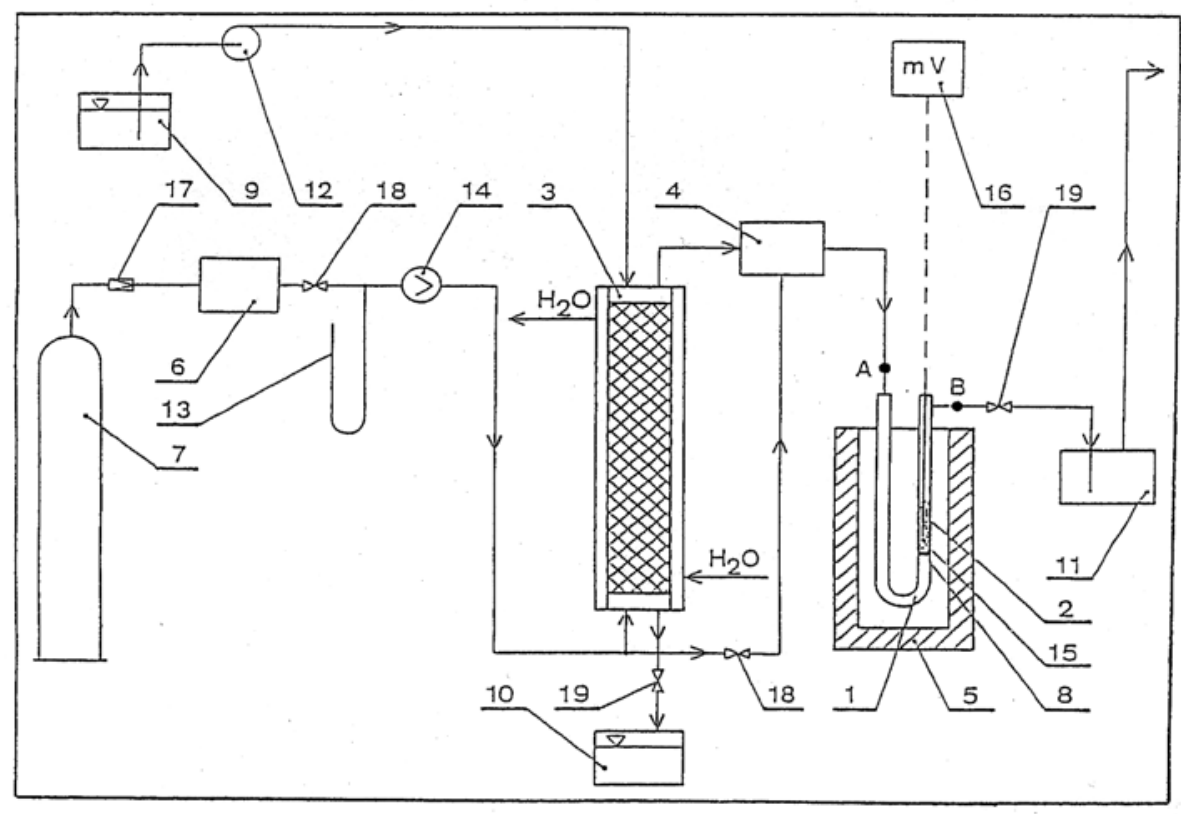

Figure 2. The experimental set-up: 1 - tubular reactor, 2 - catalyst bed, 3 - packed column (saturator), 4 - mixer of the gases, 5 - electric furnace, 6 - air purification system, 7 - high-pressure air cylinder, 8 - grate from quartz wool, $9-$ tank of methanol or n-butyl acetate, 10 - tank of the liquid from column, 11 - surge tank, 12 - peristaltic feed pump, 13 - mercury gauge, 14 - flowmeter, 15 - thermocouple, 16 - millivoltmeter, 17 - reducing valve, 18 - needle valves, 19 - control valve, A,B - sampling ports 
the samples of the gases at the inlet and outlet of the reactor (after cooling it to ambient temperature) were taken from the sampling ports using a syringe. The concentration of methanol or n-butyl acetate in the gas mixture was determined using a gas chromatograph CHROM 5, equipped with the FID detector (Porapack QS column at $110^{\circ} \mathrm{C}$ ). On the basis of the obtained results the degree of the conversion (combustion) was calculated, using the formula:

$\alpha=\frac{c_{0}-c}{c_{0}}$

The change of the volume flow rate of the gaseous mixture, as a result of the reaction, was insignificant. It was smaller than $0.4 \%$ for the concentrations of the tested organic compounds. It allowed to assume that $\dot{F}_{0 v}=\dot{F}_{v}=$ const and it accounted for the application of the above equation to the calculation of the conversion degree.

The investigations of the activity of the obtained vanadium-titanium and molybdenum- titanium catalysts and industrial Pt-p and MCA catalysts in the catalytic combustion of methanol or n-butyl acetate processes were carried out, using the constant flow rate of the reaction mixture $20 \mathrm{dm}^{3} / \mathrm{h}\left(5.56 \cdot 10^{-6} \mathrm{~m}^{3} / \mathrm{s}\right)$ in each test. The calculated space velocity was $20 \mathrm{~s}^{-1}$. The inlet concentration of methanol in the stream of the reaction mixture was in the range of $0.469-1.125 \mathrm{~mol} / \mathrm{m}^{3}\left(15-36 \mathrm{~g} / \mathrm{m}^{3}\right)$, whereas the concentration of n-butyl acetate in the range of $0.121-0.198 \mathrm{~mol} / \mathrm{m}^{3}\left(14-23 \mathrm{~g} / \mathrm{m}^{3}\right)$. In the reactor whose cross-section in the reaction zone was of $2.83 \cdot 10^{-6}$ $\mathrm{m}^{2}$ and the applied flow rate of the reaction mixture was $5.56 \cdot 10^{-6} \mathrm{~m}^{3} / \mathrm{s}$, the calculated linear velocity of the gas flow was near $0.2 \mathrm{~m} / \mathrm{s}$ (exactly $0.197 \mathrm{~m} / \mathrm{s}$ ). Taking into account the opinion of the authors ${ }^{17}$ it has been assumed that under such conditions the external diffusion does not influence the total rate of the investigated processes. For the experiments in the kinetic region the powder of the catalysts (the size of the particles in the range of $1.02-$ $1.2 \cdot 10^{-4} \mathrm{~m}$ ) were used. It was found experimentally that over such fine grains of the catalysts the process occurs in the kinetic region. The measurements in the diffusion region were performed using the grains of the catalysts with a diameter of $2.5 \cdot 10^{-3} \mathrm{~m}$.

\section{RESULTS AND DISCUSSION}

Initially, the influence of the size of the catalyst grains on the methanol combustion process rate (destruction degree) over the MCA catalyst and on the n-butyl combustion process rate over the $8 \% \mathrm{~V}_{2} \mathrm{O}_{5} / \mathrm{TiO}_{2}$ catalyst, were determined. The aim of these measurements was to find the dimensions of the catalyst grains, for which the process runs in the kinetic region. In these investigations the grains of the catalysts with the diameter in the range of $1.02 \div 1.2 \cdot 10^{-4}-2.5 \cdot 10^{-3} \mathrm{~m}$ were applied. The temperature and the inlet concentration of the pollutant in the gases were kept constant during each measurement and were $260^{\circ} \mathrm{C}$ and $20 \mathrm{~g} / \mathrm{m}^{3}$ respectively, for the combustion of methanol, whereas for the combustion of n-butyl acetate were $185^{\circ} \mathrm{C}$ and $18 \mathrm{~g} / \mathrm{m}^{3}$. In both tests the same flow rate of the reaction mixture, equal to $5.56 \cdot 10^{-6} \mathrm{~m}^{3} / \mathrm{s}$ was applied.
The function $\alpha=\mathrm{f}\left(\mathrm{R}_{0}\right)$, obtained for the combustion of methanol over the MCA catalyst is shown, for example in Figure 3.

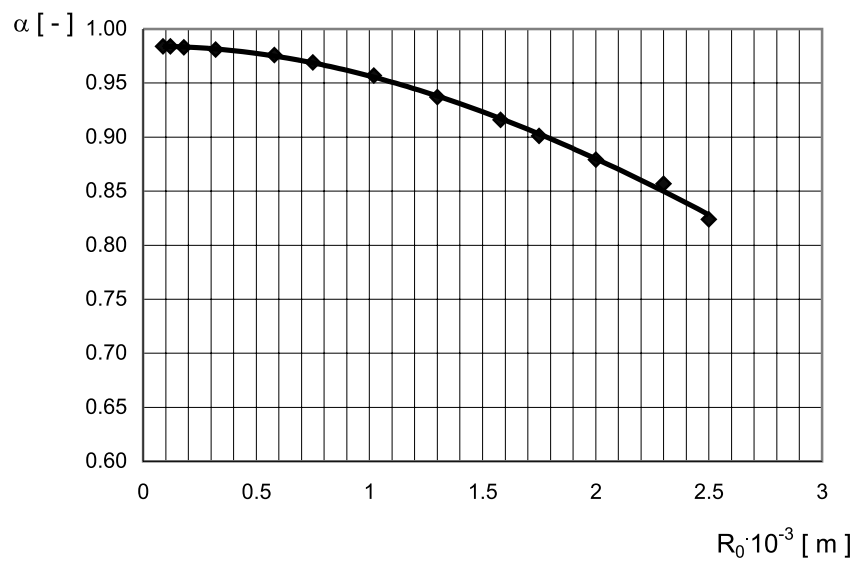

Figure 3. The relation between the conversion degree of methanol and the dimensions of MCA catalyst grains $\left(\mathrm{t}=260^{\circ} \mathrm{C}, \mathrm{c}_{0}=20 \mathrm{~g} / \mathrm{m}^{3}, \dot{F}_{0 v}=5.56 \cdot 10^{-6}\right.$ $\left.\mathrm{m}^{3} / \mathrm{s}\right)$

It is seen from the plot in Figure 3 that for the catalyst grains with the diameter of $1.8 \cdot 10^{-4} \mathrm{~m}$ (sieve fraction of $1.62-1.80 \cdot 10^{-4} \mathrm{~m}$ ) the destruction degree of methanol was near 0.98 and it did not increase when the smaller grains were used. It indicated that over such fine catalyst grains the process rate was constant and the methanol combustion process took place in the kinetic region. The same result was obtained for the combustion of n-butyl acetate over $8 \% \mathrm{~V}_{2} \mathrm{O}_{5} / \mathrm{TiO}_{2}$ catalyst. On the basis of the obtained results in further measurements in the kinetic region the powder of the catalysts with the diameter in the range of $1.02-1.2 \cdot 10^{-4} \mathrm{~m}$, were applied.

For all the applied catalysts the influence of the temperature on the conversion degree of methanol and nbutyl acetate for the kinetic region (using the powder of the catalysts) was determinated.

For example, in Figure 4 the functions $\alpha=f(t)$ for the combustion of methanol over wanadium-tytanium and industrial catalysts are shown.

It has been noticed that in the complete oxidation of methanol the most the Pt-p catalyst was the most active one. Among the other tested catalysts the $8 \% \mathrm{~V}_{2} \mathrm{O}_{5} / \mathrm{TiO}_{2}$ catalyst demonstrated the highest acitivity. The less active was the MCA industrial catalyst. The comparison of the results for the $\mathrm{V}_{2} \mathrm{O}_{5} / \mathrm{TiO}_{2}$ and the $10 \% \mathrm{~V}_{2} \mathrm{O}_{5} / \mathrm{TiO}_{2}(\mathrm{H})$ catalysts indicates that supporting vanadium oxide $(\mathrm{V})$ on carrier $\mathrm{TiO}_{2}$ in the form of hydrogel, having higher specific surface area than $\mathrm{TiO}_{2}$ anatase, leads to the improvement of the catalytic properties of the vanadium- titanium catalysts.

On the basis of the results of the investigations in the kinetic region, for each catalyst the temperature at which the conversion degree of methanol or n-butyl acetate over this catalyst reached the 0.9 value, was determinated. This temperature was taken as a measure of its activity.

The results are presented in Table 1.

The data in Table 1 for the combustion of n-butyl acetate over the applied catalysts indicate that in this process the vanadium-titanium catalysts were the most active ones. The molybdenum-titanium catalysts and the industrial catalyst Pt-p had almost the same activity, higher 


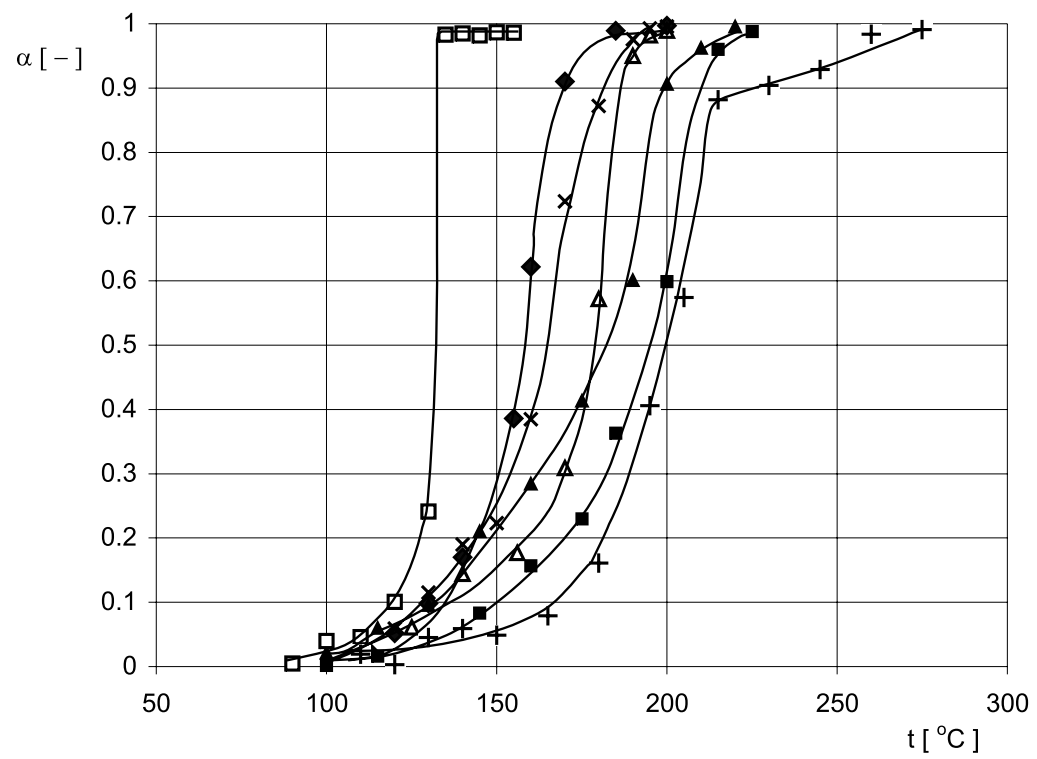

- $8 \% \mathrm{~V}_{2} \mathrm{O}_{5}$

- $10 \% \mathrm{~V}_{2} \mathrm{O}_{5}$

- $12 \% \mathrm{~V}_{2} \mathrm{O}_{5}$

x $15 \% \mathrm{~V}_{2} \mathrm{O}_{5}$

$\triangle 10 \% \mathrm{~V}_{2} \mathrm{O}_{5}(\mathrm{H})$

$\square \mathrm{Pt}-\mathrm{p}$

+ MCA

Figure 4. The influence of the temperature on the combustion degree of methanol for vanadium- titanium and industrial Pt-p and MCA catalysts (the kinetic region)

Table 1. The comparison of the activity of the catalysts for

$$
\mathbf{t}_{\alpha=0.9}
$$

\begin{tabular}{|l|c|c|}
\hline \multicolumn{1}{|c|}{ Catalyst } & $\begin{array}{c}\text { methanol } \\
{\left[{ }^{\circ} \mathrm{C}\right]}\end{array}$ & $\begin{array}{c}\text { n-butyl acetate } \\
{\left[{ }^{\circ} \mathrm{C}\right]}\end{array}$ \\
\hline $8 \% \mathrm{~V}_{2} \mathrm{O}_{5} / \mathrm{TiO}_{2}$ & 170 & 200 \\
\hline $10 \% \mathrm{~V}_{2} \mathrm{O}_{5} / \mathrm{TiO}_{2}$ & 210 & 220 \\
\hline $12 \% \mathrm{~V}_{2} \mathrm{O}_{5} / \mathrm{TiO}_{2}$ & 200 & 210 \\
\hline $15 \% \mathrm{~V}_{2} \mathrm{O}_{5} / \mathrm{TiO}_{2}$ & 185 & 205 \\
\hline $\begin{array}{l}10 \% \mathrm{~V}_{2} \mathrm{O}_{5} / \mathrm{TiO}_{2} \\
(\mathrm{H})\end{array}$ & 185 & 210 \\
\hline $8 \% \mathrm{MoO}_{3} / \mathrm{TiO}_{2}$ & 235 & 230 \\
\hline $10 \% \mathrm{MoO}_{3} / \mathrm{TiO}_{2}$ & 245 & 245 \\
\hline $12 \% \mathrm{MoO}_{3} / \mathrm{TiO}_{2}$ & 230 & 245 \\
\hline $15 \% \mathrm{MoO}_{3} / \mathrm{TiO}_{2}$ & 240 & 245 \\
\hline $\begin{array}{l}10 \% \mathrm{MoO}_{3} / \mathrm{TiO}_{2} \\
(\mathrm{H})\end{array}$ & 235 & 220 \\
\hline $\mathrm{MCA}$ & 230 & 270 \\
\hline $\mathrm{Pt}-\mathrm{p}$ & 135 & 240 \\
\hline
\end{tabular}

than the MCA catalyst. Among all the tested catalysts the most active in the catalytic combustion of n-butyl acetate was the $8 \% \mathrm{~V}_{2} \mathrm{O}_{5} / \mathrm{TiO}_{2}$. It should be noticed that the use of the catalysts based on metal oxides resulted in almost total $(\alpha=0.98 \div 0.99)$ purification of the air with methanol or n-butyl acetate at the temperatures $30-50^{\circ} \mathrm{C}$ higher than the ones given in Table 1 .

On the basis of the results of the measurements in the kinetic region for all the applied catalysts the A and B (E/ R) parameters of Arrhenius equation were calculated. For all the catalysts in the coordinate system $\operatorname{lnk} \div 1 / \mathrm{T}$ the linear plots were obtained. For example in Figure 5 the plot for the combustion of n-butyl acetate over the $8 \% \mathrm{~V}_{2} \mathrm{O}_{5} / \mathrm{TiO}_{2}$ catalyst is shown.

The Arrhenius equations, describing the rate constants of the combustion reactions for the tested catalysts are listed in Table 2.

The investigations in the diffusion region were carried out for the MCA catalyst for the combustion of methanol and n-butyl acetate and for the $8 \% \mathrm{~V}_{2} \mathrm{O}_{5} / \mathrm{TiO}_{2}$ in the combustion of methanol. For example the influence of the temperature on $-\ln (1-\alpha)$ in the combustion of methanol with the use of the powder and the grains of MCA is shown in Figure 6.

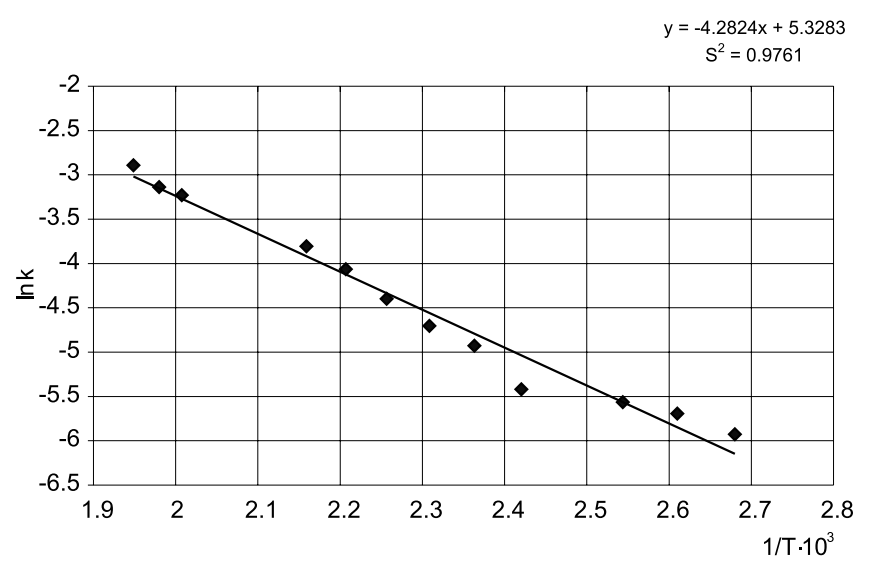

Figure 5. The relation between lnk and $1 / \mathrm{T}$. The combustion of n-butyl acetate over the $8 \% \mathrm{~V}_{2} \mathrm{O}_{5} / \mathrm{TiO}_{2}$ catalyst

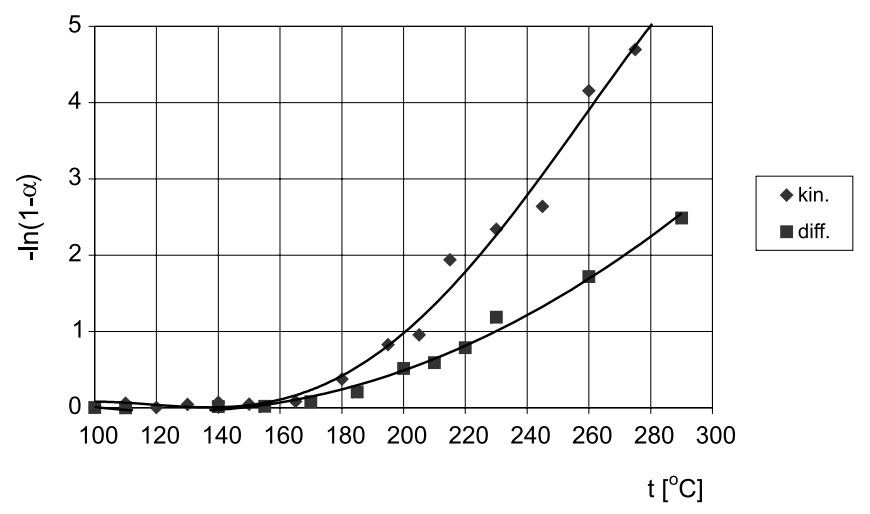

Figure 6. Functions $-\ln (1-\alpha)=f(t)$ for the combustion of the methanol over MCA in the kinetic and diffusion region

The measurements were performed using the same flow rate of the reaction mixture $\left(20 \mathrm{dm}^{3} / \mathrm{h}\right)$. It has been noted that the internal diffusion has an influence on the process rate, especially at higher temperatures. At the same temperature the process rate in the diffusion region is much lower than in the kinetic region.

The results were elaborated as follows. At first, on the basis of the dependences $-\ln (1-\alpha)=f(t)$ obtained for both regions the effectivity coefficient $\eta$ can be determined. Then, from the dependence in Fig.1 the value of Thiele's 
Table 2. The Arrhenius equations. The catalytic combustion of methanol and n-butyl acetate

\begin{tabular}{|l|c|c|}
\hline \multirow{2}{*}{ Catalyst } & \multicolumn{2}{|c|}{$\mathrm{k}=\mathrm{A} \exp (-\mathrm{B} / \mathrm{T})$} \\
\cline { 2 - 3 } & \multicolumn{1}{|c|}{ methanol } & $\mathrm{n}-$ butyl acetate \\
\hline $8 \% \mathrm{~V}_{2} \mathrm{O}_{5} / \mathrm{TiO}_{2}$ & $\mathrm{k}=1.4613 \cdot 10^{8} \exp (-9826 / \mathrm{T})$ & $\mathrm{k}=2.7819 \cdot 10^{2} \exp (-4282 / \mathrm{T})$ \\
\hline $10 \% \mathrm{~V}_{2} \mathrm{O}_{5} / \mathrm{TiO}_{2}$ & $\mathrm{k}=3.9825 \cdot 10^{7} \exp (-10085 / \mathrm{T})$ & $\mathrm{k}=5.4176 \cdot 10^{4} \exp (-7187 / \mathrm{T})$ \\
\hline $12 \% \mathrm{~V}_{2} \mathrm{O}_{5} / \mathrm{TiO}_{2}$ & $\mathrm{k}=5.9720 \cdot 10^{5} \exp (-8232 / \mathrm{T})$ & $\mathrm{k}=1.09610 \cdot 10^{3} \exp (-5718 / \mathrm{T})$ \\
\hline $15 \% \mathrm{~V}_{2} \mathrm{O}_{5} / \mathrm{TiO}_{2}$ & $\mathrm{k}=3.2522 \cdot 10^{8} \exp (-10573 / \mathrm{T})$ & $\mathrm{k}=2.9887 \cdot 10^{2} \exp (-4529 / \mathrm{T})$ \\
\hline $10 \% \mathrm{~V}_{2} \mathrm{O}_{5} / \mathrm{TiO}_{2}(\mathrm{H})$ & $\mathrm{k}=1.4613 \cdot 10^{8} \exp (-10499 / \mathrm{T})$ & $\mathrm{k}=6.6686 \cdot 10 \exp (-3876 / \mathrm{T})$ \\
\hline $8 \% \mathrm{MoO}_{3} / \mathrm{TiO}_{2}$ & $\mathrm{k}=2.9810 \cdot 10^{3} \exp (-6033 / \mathrm{T})$ & $\mathrm{k}=1.4841 \cdot 10^{2} \exp (-4460 / \mathrm{T})$ \\
\hline $10 \% \mathrm{MoO}_{3} / \mathrm{TiO}_{2}$ & $\mathrm{k}=4.0238 \cdot 10^{3} \exp (-6307 / \mathrm{T})$ & $\mathrm{k}=1.0910 \cdot 10^{5} \exp (-7993 / \mathrm{T})$ \\
\hline $12 \% \mathrm{MoO}_{3} / \mathrm{TiO}_{2}$ & $\mathrm{k}=2.6834 \cdot 10^{5} \exp (-8634 / \mathrm{T})$ & $\mathrm{k}=4.9275 \cdot 10^{2} \exp (-5328 / \mathrm{T})$ \\
\hline $15 \% \mathrm{MoO}_{3} / \mathrm{TiO}_{2}$ & $\mathrm{k}=1.2088 \cdot 10^{4} \exp (-6776 / \mathrm{T})$ & $\mathrm{k}=3.6316 \cdot 10^{4} \exp (-7120 / \mathrm{T})$ \\
\hline $10 \% \mathrm{MoO}_{3} / \mathrm{TiO}_{2}(\mathrm{H})$ & $\mathrm{k}=1.9776 \cdot 10^{7} \exp (-10638 / \mathrm{T})$ & $\mathrm{k}=3.3030 \cdot 10^{2} \exp (-5138 / \mathrm{T})$ \\
\hline $\mathrm{MCA}$ & $\mathrm{k}=5.9874 \cdot 10^{4} \exp (-7515 / \mathrm{T})$ & $\mathrm{k}=4.4471 \cdot 10^{3} \exp (-5922 / \mathrm{T})$ \\
\hline $\mathrm{Pt}-\mathrm{p}$ & $\mathrm{k}=3.1856 \cdot 10^{16} \exp (-17312 / \mathrm{T})$ & \\
\hline
\end{tabular}

modulus is estimated. The rate constant of reaction $\mathrm{k}_{\mathrm{v}}$ is calculated using the Arrhenius equation for the tested catalyst. Next, the effective coefficient of diffusion $\mathrm{D}_{\mathrm{ef}}$ is calculated (equation 5).

For example, the results of the calculations for the MCA catalyst are listed in Table 3.

Table 3. The results of the calculations. The combustion of methanol over MCA $\left(r_{k}=1800 \mathrm{~kg} / \mathrm{m}^{3}\right)$. Diffusion region

\begin{tabular}{|c|c|c|c|c|}
\hline $\begin{array}{c}T \\
{[\mathrm{~K}]}\end{array}$ & $\begin{array}{c}\eta \\
{[-]}\end{array}$ & $\begin{array}{c}\Phi_{\mathrm{s} 1} \\
{[-]}\end{array}$ & $\begin{array}{c}\mathrm{k}_{\mathrm{v}} \\
{[1 / \mathrm{s}]}\end{array}$ & $\begin{array}{c}\mathrm{D}_{\text {ef }} \cdot 10^{6} \\
{\left[\mathrm{~m}^{2} / \mathrm{s}\right]}\end{array}$ \\
\hline 423.15 & 1 & - & 1.00 & - \\
\hline 438.15 & 0.67 & 3.00 & 1.65 & 1.15 \\
\hline 453.15 & 0.55 & 4.22 & 3.51 & 1.23 \\
\hline 468.15 & 0.53 & 4.25 & 10.53 & 3.64 \\
\hline 478.15 & 0.50 & 4.75 & 17.09 & 4.73 \\
\hline 488.15 & 0.44 & 5.45 & 42.80 & 9.01 \\
\hline 503.15 & 0.43 & 5.60 & 46.81 & 9.33 \\
\hline 518.15 & 0.43 & 5.60 & 52.76 & 10.51 \\
\hline 533.15 & 0.42 & 5.75 & 83.13 & 15.71 \\
\hline 548.15 & 0.41 & 5.85 & 93.96 & 17.16 \\
\hline
\end{tabular}

As it can be seen from the results, the effective coefficients of diffusion calculated for higher temperatures (up $488.15 \mathrm{~K}$ ) have the values in accordance with the values given in literature ${ }^{\mathbf{1 8}}$. At lower temperatures the differences between the reaction rates in both regions are very small. It makes the precise determination of the effective coefficient of diffusion difficult and results in obtaining too low values. Therefore, for the design calculations the values calculated for higher temperatures of the process should be taken.

The measurements and calculations chosen in this research allow to obtain the kinetic data necessary to design the reactors for catalytic combustion.

\section{TESTS OF CATALYST STRUCTURE}

The aim of the investigations of the structure of metal oxides supported on the $\mathrm{TiO}_{2}$ catalysts was to explain why their high activity in the combustion of organic compounds is so high.

In Figures 7 and 8 the SEM images of the surfaces of the $\mathrm{V}_{2} \mathrm{O}_{5}$ and $8 \% \mathrm{~V}_{2} \mathrm{O}_{5} / \mathrm{TiO}_{2}$ catalyst, obtained with the use of scanning electron microscope are shown.

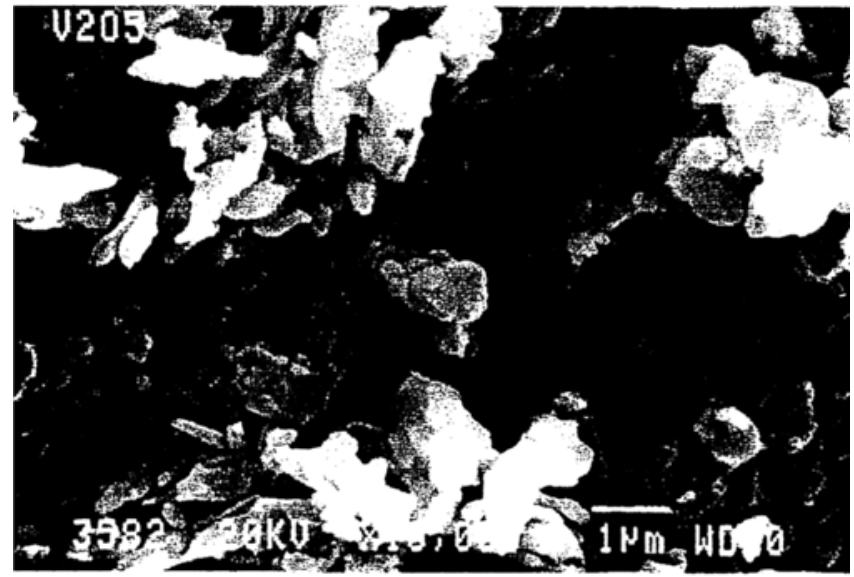

Figure 7. The SEM images of the $\mathrm{V}_{2} \mathrm{O}_{5}$

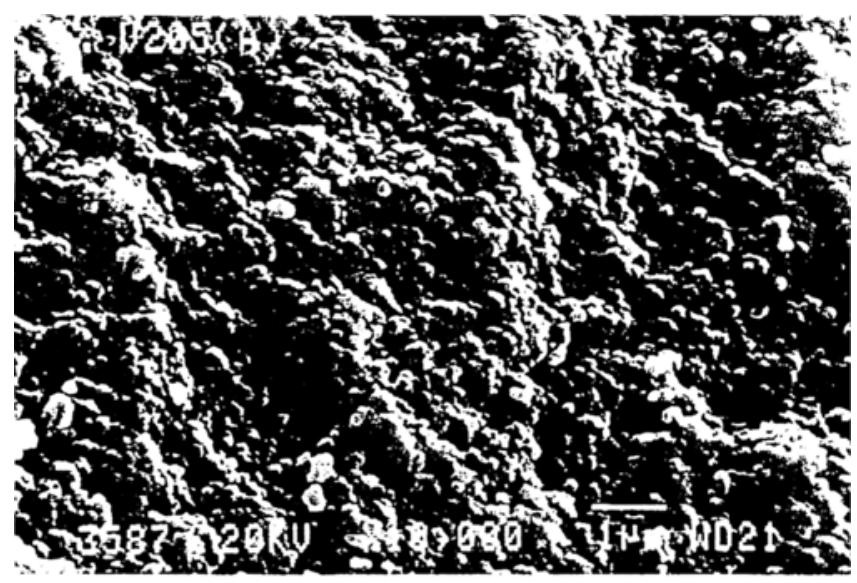

Figure 8. The SEM images of $8 \% \mathrm{~V}_{2} \mathrm{O}_{5} / \mathrm{TiO}_{2}$ catalyst

It can be seen, that dispersion of vanadium oxide $(\mathrm{V})$ on the surface of the catalyst is high. The same results were observed for other used catalysts.

In Figure 9 the IR spectra of the $10 \% \mathrm{~V}_{2} \mathrm{O}_{5} / \mathrm{TiO}_{2}$ catalyst is presented.

On the catalyst spectra the wavenumbers calculated for the $\mathrm{V}_{2} \mathrm{O}_{5}-\mathrm{TiO}_{2}$ system by the $\mathrm{ZINDO} / \mathrm{S}$ method (using the HYPERCHEM application) are marked by vertical lines. A good agreement between the calculated and the measured wavenumbers was obtained. On the basis of these results it has been stated that the values of wavenumbers correspond with pure compounds i.e. $\mathrm{V}_{2} \mathrm{O}_{5}$ and $\mathrm{TiO}_{2}$ or the aggregates of these compounds. 


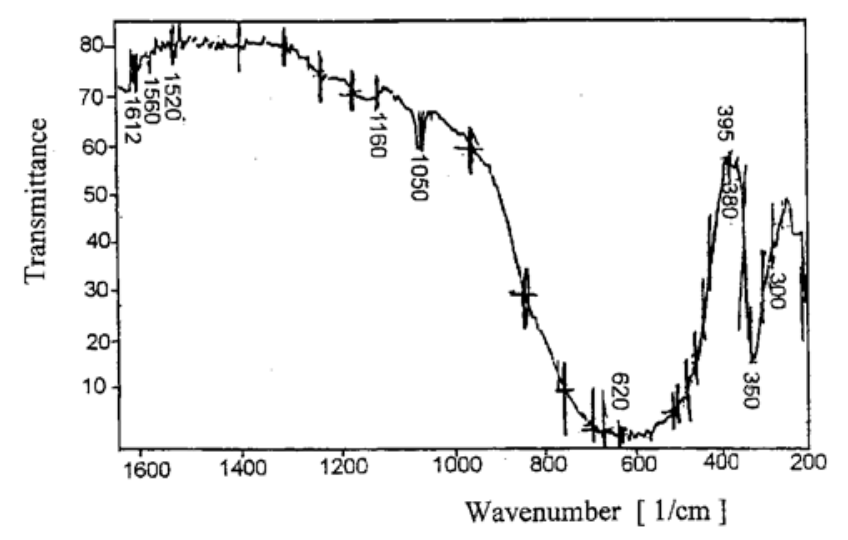

Figure 9. The IR spectra of the $10 \% \mathrm{~V}_{2} \mathrm{O}_{5} / \mathrm{TiO}_{2}$ catalyst

For all the catalysts based on metal oxides, the X-ray diffraction analysis was also applied. On the basis of the obtained XRD patterns for the applied catalysts it has been stated that these catalysts didn't contain any new phase, which can be treated as a reason for their high activity.

The results of the investigations of the catalyst structures indicated that the tested catalysts didn't contain any new phase, besides the pure oxides $\mathrm{V}_{2} \mathrm{O}_{5}, \mathrm{MoO}_{3}$ and $\mathrm{TiO}_{2}$. The main reason for their high activity in the combustion of organic compounds processes is probably a high dispersion of active components on the surface of the $\mathrm{TiO}_{2}$ carrier.

\section{CONCLUSIONS}

- The catalysts obtained by supporting $\mathrm{V}_{2} \mathrm{O}_{5}$ and $\mathrm{MoO}_{3}$ on the $\mathrm{TiO}_{2}$ carrier demonstrate high activity in the catalytic oxidation (combustion) of VOCs (methanol and nbutyl acetate) processes. As the carrier for these catalysts the titanium oxide in the form of anatase and hydrogel can be used.

- The tested metal oxides catalysts were more active than the industrial Pt-p and MCA catalysts in the combustion of the n-butyl acetate process. They were also more active (vanadium-titanium catalysts) and had the same activity (molybdenum- titanium catalysts) as MCA in the combustion of methanol. The most active in this process was the industrial Pt-p catalyst.

- The applied catalysts worked effectively at low temperatures under the load of $20 \mathrm{~s}^{-1}$. The conversion degree $\alpha=0.9$ of n-butyl acetate was achieved at the temperatures in the range of $200-270^{\circ} \mathrm{C}$, but for methanol in the range of $170-245^{\circ} \mathrm{C}$ over metal oxides catalysts and at temperature of $135^{\circ} \mathrm{C}$ over the Pt-p catalyst.

- The most active in the combustion of methanol were Pt-p and the $8 \% \mathrm{~V}_{2} \mathrm{O}_{5} / \mathrm{TiO}_{2}$, whereas in the combustion of n-butyl acetate the $8 \% \mathrm{~V}_{2} \mathrm{O}_{5} / \mathrm{TiO}_{2}$ and the $10 \% \mathrm{~V}_{2} \mathrm{O}_{5} /$ $\mathrm{TiO}_{2}$.

- The reaction rate of the combustion of methanol or n-butyl acetate in the air can be described by the first order equation in relation to the concentration of an organic compound in the stream of gases.

- The measurements in the kinetic region of the rate constant depending on the temperature (Arrhenius equations) can be used to design the catalytic reactor for the catalytic combustion of methanol or n-butyl acetate over the applied catalysts.
- The applied method for the description of the combustion process controlled by the internal diffusion (over the grains of the catalyst of $2.5 \mathrm{~mm}$ in diameter) describes well the kinetics of this process in a real reactor, where the pellet or blocks catalysts are usually used. The effective coefficients calculated on the basis of the tests in the diffusion region for the MCA catalyst had the same values as given in the literature.

- The traditional instrumental methods of the examination of the catalysts' structure didn't explain exactly the reason for their high activity. The results of these analysis indicated, that the catalysts contain only pure phases i.e. $\mathrm{V}_{2} \mathrm{O}_{5}, \mathrm{MoO}_{3}$ and $\mathrm{TiO}_{2}$. It has also been stated that the dispersion of active components on the surface of the carrier is high.

- The vanadium-titanium and molybdenum - titanium catalysts, especially the most active of them the $8 \% \mathrm{~V}_{2} \mathrm{O}_{5} /$ $\mathrm{TiO}_{2}$ catalyst can be applied in the industrial system for the purification of the effluent gases and the air with VOCs, replacing the more expansive catalysts based on noble metals.

\section{Nomenclature}

$A$

$B=E / R$

- the pre-exponential Arrhenius factor, $\mathrm{s}^{-1}$ or $\mathrm{m}^{3} / \mathrm{kg} \cdot \mathrm{s}$

- the parameter of the Arrhenius equation

$c_{0} \quad-$ inlet concentration of the pollutant, $\mathrm{mol} / \mathrm{m}^{3}$

c - outlet concentration of the pollutant, $\mathrm{mol} / \mathrm{m}^{3}$

$D_{e f} \quad-$ effective coefficient of diffusion, $\mathrm{m}^{2} / \mathrm{s}$

$E \quad-$ the apparent activation energy, $\mathrm{J} / \mathrm{mol}$

$\dot{F}_{0 v} \quad-$ flow rate of the reaction mixture, $\mathrm{m}^{3} / \mathrm{s}$, $\mathrm{dm}^{3} / \mathrm{h}$

$\dot{F}_{v} \quad-$ flow rate of the post-reaction mixture, $\mathrm{m}^{3} / \mathrm{s}, \mathrm{dm}^{3} / \mathrm{h}$

$k=k_{v} / \rho_{k} \quad-$ rate constant of the reaction determinated for the unit mass of the catalyst, $\mathrm{m}^{3} / \mathrm{kg}_{\mathrm{k}} \cdot \mathrm{s}$

$k_{v} \quad-$ rate constant of the reaction per unit volume of the catalyst grain, $\mathrm{s}^{-1}$

$m_{k} \quad-$ mass of the catalyst, $\mathrm{kg}$

$R \quad-$ gas constant, $\mathrm{J} / \mathrm{mol} \cdot \mathrm{K}$

$R_{0} \quad-$ radius of the catalyst grain, $\mathrm{m}$

$r_{0} \quad-$ reaction rate, $\mathrm{mol} / \mathrm{m}^{3} \cdot \mathrm{s}$

$r(\alpha, T) \quad-$ the process rate, $\mathrm{mol} / \mathrm{m}^{3} \cdot \mathrm{s}$

$S^{2} \quad-$ correlation coefficient

$t \quad$ - temperature, ${ }^{\circ} \mathrm{C}$

$T \quad$ - temperature, $\mathrm{K}$

$\alpha-$ conversion (combustion ) degree

$\eta \quad-$ effectivity coefficient

$\rho_{k} \quad-$ density of the catalyst, $\mathrm{kg} / \mathrm{m}^{3}$

$\tau \quad-$ time, $\mathrm{s}$

$\Phi_{s 1} \quad-$ the Thiele's modulus

\section{LITERATURE CITED}

1. Konieczyński, J.(1993). Oczyszczanie gazów odlotowych, Published by Silesian Technical University, Gliwice, Poland.

2. Wojciechowski, J. (1992). Oczyszczanie gazów metoda Swingtherm-doświadczenia z 10 lat eksploatacji, Przemysł Chemiczny, 71 (6), 230 - 232.

3. Avgourpoulos, G., Oikonomopoulos E., Kanistras D. \& Ioannides, T. (2006). Applied Catalysis B: Environmental, Complete oxidation of ethanol over alkali-promoted Pt/Al $\mathrm{O}_{3}$ catalysts, 65, 62 - 69. DOI: 10.1016/j.apcatb.2005.12.016. 
4. Tsou, J., Magnoux P., Guisnet M., Órfao, J.J.M. \& Figueiredo, J. L. (2005). Catalytic oxidation of volatile organic compounds. Oxidation of methyl-isobutyl-ketone over Pt/zeolite catalysts. Applied Catalysis B: Environmental, 57, 117 - 123. DOI: 10.1016/j. apcatb.2004.10.013.

5. Baker, J.E., Burch R. \& Golunski S.E.(1989). Thermal Analysis of catalyst surfaces. Termochimica Acta, 142 (2), 329 342. DOI:10.1016/0040-6031(89)85029-4.

6. Nowicki, B. \& Masiarz, A.(1995). Badania nowych katalizatorów platynowych do oczyszczania gazów z zanieczyszczeń organicznych i tlenku węgla. Przemysł Chemiczny, 74 (3), 100 102.

7. Agarwal, S.K., Spivey, J. \& Butt, J.B. (1992). Deep oxidation of hydrocarbons, Applied Catalysis A: General, 81(2), 239255. DOI: 10.1016/0962-860X(92)80096-U.

8. Straszko, J., Szpilski, W. \& Kalisiak, B.(1994). Katalizatory procesu spalania toksycznych domieszek powietrza. Przemysł Chemiczny, 73 (5), 176 - 178.

9. Nowicki, J. \& Masiarz, A.(1992). Badania aktywności krajowych katalizatorów tlenkowych $w$ procesie utleniania tlenku węgla. Przemysł Chemiczny, 71 (9), 344 - 346.

10. Spivey, J.J. (1987). Complete catalytic oxidation of volatile organics. Ind. Eng. Chem. Res., 27 (11), 2165 - 2180. DOI: 10.1021/ie00071a001.

11. Wang, C.-H. (2004). $\mathrm{Al}_{2} \mathrm{O}_{3^{-}}$supported transition-metal oxides for catalytic incineration of toluene. Chemosphere, 55 (1), 11 - 17. DOI: 10.1016/j.chemosphere.2003.10.036.

12. Kennedy, L.A. \& Ruckenstein, E. (1984). Catalytic combustion, Catalysis Reviews, 26 (1), 1 - 58. DOI: 10.1080/ 0161498408078059.

13. Drago, R.S., Jurczyk, K., Singh, D.J. \& Young, V.(1995). Low-temperature deep oxidation of hydrocarbons by metal oxides supported on carbonaceous materials. Applied Catalysis B: Environmental. 6, 155 - 168. DOI: 10.1016/0926-3373(95)00009-7.

14. Matsuda, S. \& Kato, A.(1983). Titanium oxide based catalysts - a review. Applied Catalysis B: Environmental. 8 (2), 149 - 165, DOI: 10.1016/0166-9834(83)80076-1.

15. Kato, Y. (JP ) \& Konishi, K. (JP), ( Babcock Hitachi KK, JP ). ( June 1993 ). Catalyst for purifying exhaust gas. EUROPEAN PATENT APPLICATION. Patno. EP0544282.

16. Straszko, J. (1979). Modelowanie kinetyki procesów kontaktowych. Unpublished dissertation, Szczecin Univerisy of Technology, Poland.

17. Szarawara, J.\& Skrzypek, J.(1980). Podstawy inżynierii reaktorów chemicznych, WNT, Warszawa, Poland.

18. Kaczanowska- Lawniczak, Z. (1982). Dyfuzja mieszanin $w$ porowatych katalizatorach $i$ sorbentach przemystowych. Unpublished doctoral dissertation, Szczecin University of Technology, Poland. 